\title{
Variation in species assemblages due to micro-topography and flow regime govern vegetation carbon stock in seasonal floodplain wetlands
}

Priyanka Sarkar ${ }^{1}$, Tapati Das ${ }^{1 *}$ and Dibyendu Adhikari ${ }^{2}$

\begin{abstract}
Hypothesis: Variation in species assemblages due to micro-topographic features and flow regime determine vegetation carbon stock in floodplain wetlands.

Material and method: We tested this hypothesis in Chatla - a tropical floodplain wetland located in northeast India. Five sampling stations characterized by contrasting micro-topographic and flow parameters were selected in the wetland for study. Species composition, assemblage pattern, and vegetation carbon stock were studied in these stations during three flood phases, i.e., early, middle, and late flood phases following standard methods. Univariate and multivariate statistics were used to determine the relationship between the selected environmental parameters, plant species assemblages, and vegetation carbon stock of the wetland.

Results: Thirty-one species of herbs and five species of shrubs were recorded from the five stations in Chatla floodplain wetland. Flow regime characterized by water flow velocity and discharge showed substantial variations across the stations. These parameters in turn are related to variations in the micro-topographic characteristics namely depth, width, and cross-sectional area of the stations. Plant species composition and abundance differed significantly with respect to micro-topography and flow regime as revealed by the cluster diagram. The canonical correspondence analysis revealed strong association of plant species assemblages with the micro-topography and flow regime within the wetland. Multiple regression analysis revealed a significant positive relationship of the vegetation carbon stock with the water discharge.
\end{abstract}

Conclusions: Spatial variation in plant species diversity because of micro-topography and flow regime determines the vegetation carbon stock in floodplain wetlands. Modification of these parameters by anthropogenic activities such as mining and quarrying may potentially influence the carbon stocking potential of seasonal floodplain wetlands. Therefore, appropriate measures should be taken to maintain the integrity of the natural topographic features of such wetlands.

Keywords: Riparian vegetation, Tropical wetland, Vegetation biomass, Ecosystem services, Northeast India

\footnotetext{
* Correspondence: dr.tapatidas@gmail.com

'Department of Ecology and Environmental Science, Assam University,

Silchar 788011, India

Full list of author information is available at the end of the article
} 


\section{Introduction}

Tropical floodplain wetlands provide numerous ecological services through regulation of hydrological cycle, facilitation of groundwater recharge, controlling flood risk by modifying the river discharge, and support diverse livelihood activities (Costanza et al. 1997; Tockner and Stanford 2002; Murphy et al. 2003; Mitsch and Gosselink 2015). They are also one of the most carbon-rich ecosystems storing $\sim 250 \mathrm{Gt}$ of carbon (Neue et al. 1997; Bernal and Mitsch 2013; Kolka et al. 2016). Particularly, seasonal floodplain wetlands act as a significant carbon sink by sequestering vast amounts of organic carbon in soil and vegetation ranging from 69.2 to $114.3 \mathrm{~g} \mathrm{C} \mathrm{m}^{-2}$ year $^{-1}$, that could help in mitigating the impact of climate change (Walling et al. 2006; Cierjacks et al. 2010; Sutfin et al. 2016; Craft et al. 2018).

The carbon stocking capacity of wetlands is modulated by various environmental factors such as climate, hydrology, soil, vegetation, land conversion, and management practices (Adame et al. 2015; Kolka et al. 2016; Watkins et al. 2017). The effect of these factors may be understood at various spatial, e.g., local, regional, and global, and temporal frames of reference, e.g., ten to hundreds of years (Carnell et al. 2018). Nevertheless, to design and implement effective management strategies, it is necessary to understand how the proximal abiotic factors influence the pattern and mechanism of carbon stocking in tropical wetlands (Mitra et al. 2005; Kolka et al. 2016).

Unplanned urbanization and infrastructure development resulting in modification of micro-topography and flow threaten the integrity of freshwater ecosystems thereby disrupting the provisioning and regulating services (Kumar et al. 2008; Zhao et al. 2006; Bassi et al. 2014). It is important to understand the mechanism, as to how variation in the micro-topographic settings may affect the aquatic ecosystem structure and function. Topographic features and water flow regime are arguably among the key factors influencing wetland ecosystem functioning (Adhikari et al. 2009; McLaughlin and Cohen 2013). Especially in floodplain wetlands, the fluvial action of flooding under a particular set of basin structure creates a mosaic of habitat patches across the landscape (Ward et al. 1999). Here, some species may be restricted to permanently flooded stagnant wetlands, while the others are found in the areas experiencing fluctuating hydroperiods (Conner and Day Jr 1982; Cherry 2011). Nonetheless, plant assemblages are also strongly influenced by the topographic variations in the aquatic ecosystems, which are the result of the incoming water and sediment regimes in the fluvial system (Bendix and Hupp 2000). Such variation in the topography creates a depth gradient to which the aquatic plants exhibit various physiological adaptations (Lacoul and Freedman 2006). Thus, the environmental factors such as micro-topographic settings and flow variation profoundly influence the structure and function of the wetland ecosystems by affecting species richness, diversity, productivity, organic matter accumulation, and nutrient cycling (Bendix and Hupp 2000; Van Der Valk 2005; Elosegi et al. 2010; McLaughlin and Cohen 2013).

In the present study, we hypothesized that variation in the plant species assemblages due to different microtopographic and water flow regime should influence the vegetation carbon stock in tropical floodplain wetlands. We tested this hypothesis in Chatla-a tropical seasonal floodplain wetland in the Barak river basin of Assam in Northeast India. The aims of our study were to investigate whether (1) differences in the wetland microtopography and flow regime cause heterogeneous environmental conditions, (2) the environmental heterogeneity influences plant species assemblage and abundance patterns, and (3) all of these factors influence the vegetation carbon stock in the wetland.

\section{Materials and methods}

\section{Study area}

We have undertaken the present study in Chatla-a seasonal floodplain wetland located in Cachar district of the state of Assam in northeast India (Fig. 1). The wetland is a part of the Barak river system, and retains water during pre-monsoon to post-monsoon periods, i.e., from April to October; and, experiences a dry phase mostly during the winter to early phase of pre-monsoon, i.e., from November to March (Fig. 2). The topography of Chatla is characterized by lowlying areas covering an area of $\sim 10 \mathrm{~km}^{2}$ with mosaics of numerous small hillocks. The primary inlet points of Chatla comprise of streams namely Jalengachhara, Baluchhara, and Salganga, among which the streams Jalengachhara and Baluchhara confluence before entering Chatla (Kar et al. 2008). The only outlet point is river Ghagra-a tributary of river Barak (Kar et al. 2008) which is a part of the Surma-Meghna river system in the Indian subcontinent. As the fluvial pattern in seasonally inundated Chatla changes with a change in seasonal rainfall, the study was carried out during the flood, when the entire wetland was inundated and turned into a continuous system.

Considering the spatiotemporal variations in microtopography and water flow regime in Chatla, five sampling stations comprising of two inlet points (stations 1 and 3), two middle points (stations 3 and 4), and one outlet point (station 5) were selected in the wetland (Fig. 1). In each sampling station, measurements of wetland micro-topography and sampling of wetland vegetation were done during each flood stage namely early flood phase (EFP; May to June), mid-flood phase (MFP; July to 


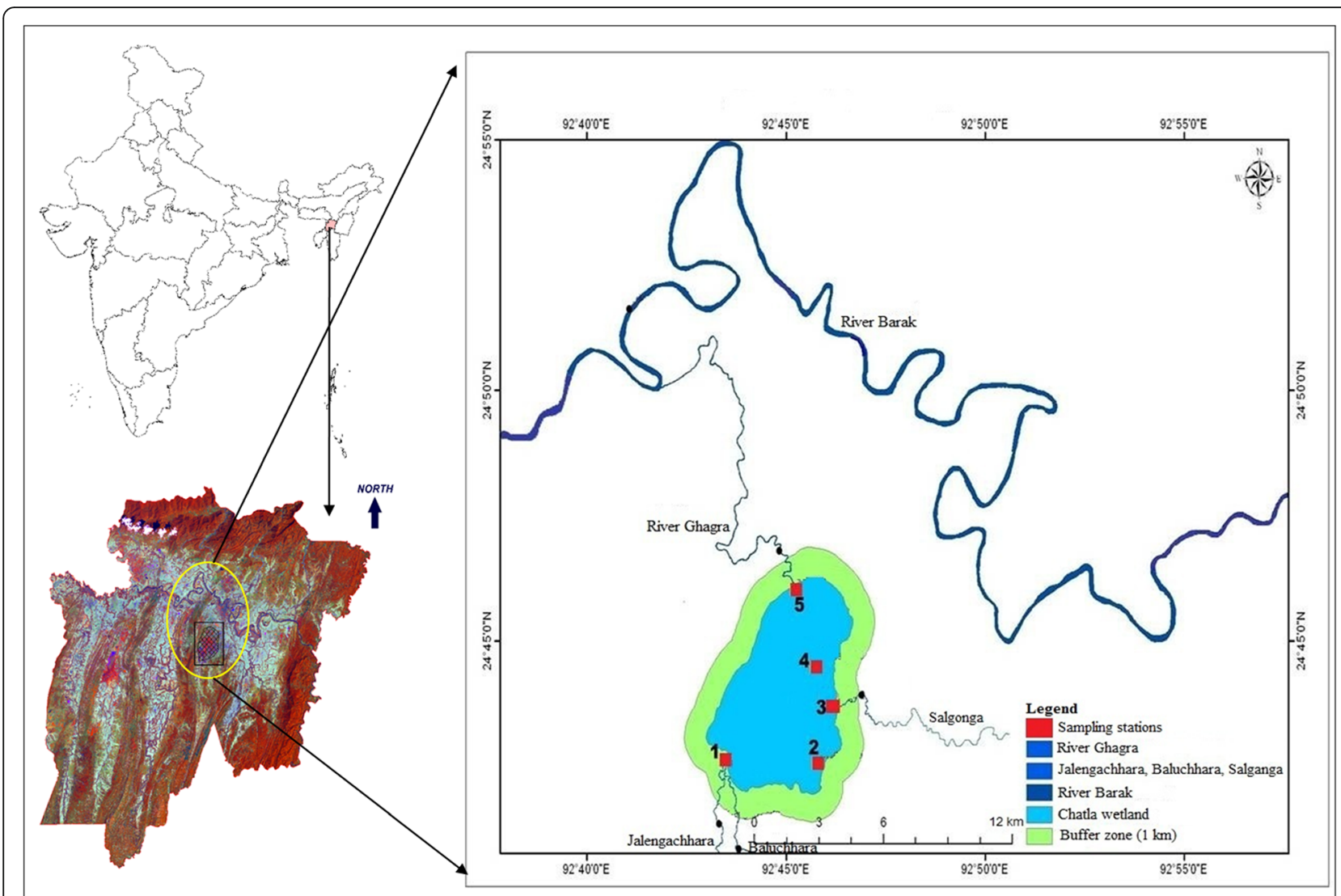

Fig. 1 Location of Chatla wetland and the sampling stations. Station 1, inlet point 1; station 2, middle point 1; station 3, inlet point 2; station 4, middle point 2; and station 5, outlet point

August), and late flood phase (LFP; September to October) during years 2014 and 2015 (Fig. 3).

\section{Micro-topographic features and water flow regime}

The micro-topographic features of the wetland examined were depth, width, and cross-sectional area. Also, the flow regime examined in this study includes average water velocity and water discharge. During each sampling period, the depth measurements $(n=5)$ in each sampling stations were done using a measuring pole while the width in the inlet $(n=5)$ and outlet points $(n=5)$ was measured using a measuring tape. The widths in the middle points of the wetland at 2 locations were measured using the line ruler tool of Google earth pro software version by plotting the respective GPS coordinates for the months of June, August, October for 2014 and 2015.

Cross-sectional area in each of the sampling station was calculated by multiplying the corresponding depth and width values of the respective sampling stations (Karume et al. 2016). All the micro-topographic and flow parameters were measured several times $(n=5)$ in each sampling stations during each flood phase. Average water velocity and water discharge at the inlets and outlet point where lotic condition prevailed during the flood phases were determined following the float method (Gordon et al. 2004) using the equations below.

$$
\text { Average water velocity }\left(\mathrm{m} \mathrm{s}^{-1}\right)=\frac{L}{t} \times k \ldots
$$

where $L$ is the distance $(\mathrm{m})$ traveled by the float in time $t(\mathrm{~s})$ and $k$ is the bed roughness coefficient $(0.85)$

$$
\text { Water discharge }\left(\text { cubic } \mathrm{m} \mathrm{s}^{-1}\right)=V A \ldots \ldots \ldots \ldots
$$

where $V$ is the average water velocity $\left(\mathrm{m} \mathrm{s}^{-1}\right)$ and $A$ is the cross-sectional area $\left(\mathrm{m}^{2}\right)$.

\section{Sampling and analysis of wetland vegetation}

We studied the species composition, diversity, and community characteristics of the lower angiosperm groups of the riparian vegetation by laying ten random quadrats of $1 \times 1 \mathrm{~m}$ size along the riparian zone of each sampling station during each flood phases for two consecutive years. Overall, 300 quadrats were sampled during the entire survey period. Plant species were identified using 


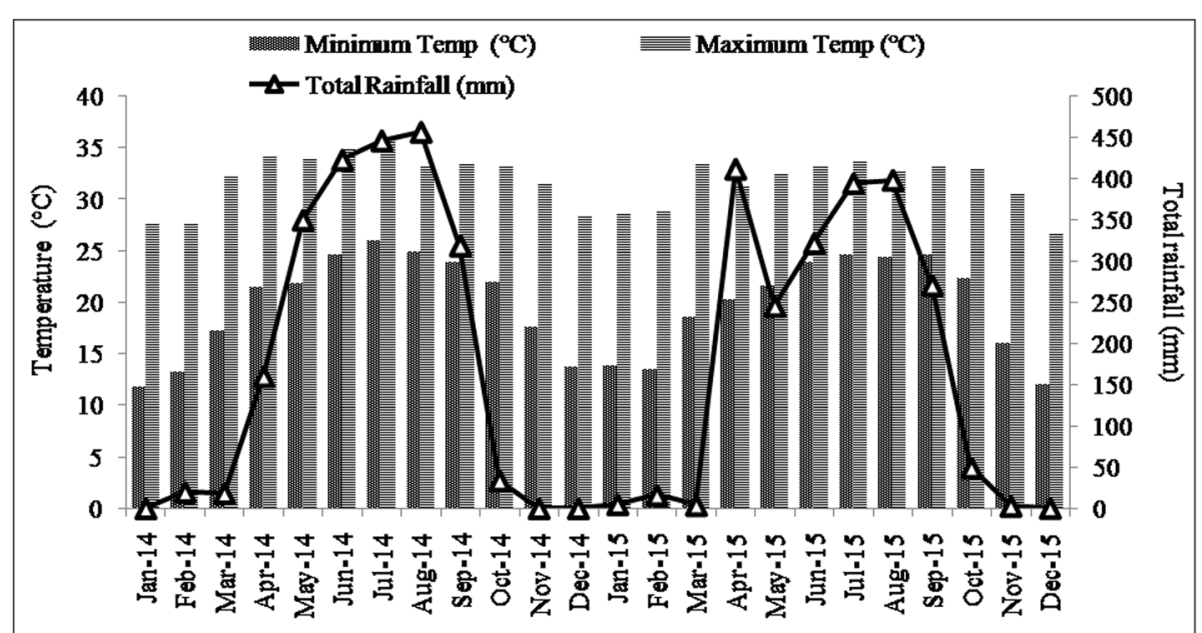

Fig. 2 Monthly variations in total rainfall and atmospheric temperature in Cachar district during study period (2014-2015). The study was carried out during early-flood phase (EFP; May to June), mid-flood phase (MFP; July to August) and late flood phase (LFP; September to October)

regional floras of Kanjilal et al. (Kanjilal et al. 1934, 1936, 1938, 1940), online database www.theplantlist.org, and the herbaria of the Botanical Survey of India (BSI), Shillong. The community characteristics such as frequency, density, basal area, relative frequency, relative density, relative basal area, and importance value index (IVI, a measure of the dominance of a species) were determined following standard methods (Kent 2011).

Plant species richness and diversity indices for the sampling stations were calculated using Shannon-Wiener diversity index (Shannon and Wiener 1963), Simpson dominance index (Simpson 1949), and Buzas and Gibson's Evenness index (Buzas and Gibson 1969). Taxonomic distinctness was determined using three levels of taxonomic information such as species, genus, and family (Warwick and Clarke 1995; Clarke and Warwick 1998). Cluster analysis using Euclidean distance was also done to identify the similarity and dissimilarity in the assemblage of the wetland vegetation across the selected sampling stations (Krebs 1989). Computation of all the abovementioned parameters of the wetland vegetation was performed using PAST software (version 3.22) (Hammer 2011).

\section{Biomass and carbon stock estimation of wetland vegetation}

Above- and below-ground biomass and carbon stock of the wetland vegetation was estimated using representative plant samples collected from three random quadrats of 1

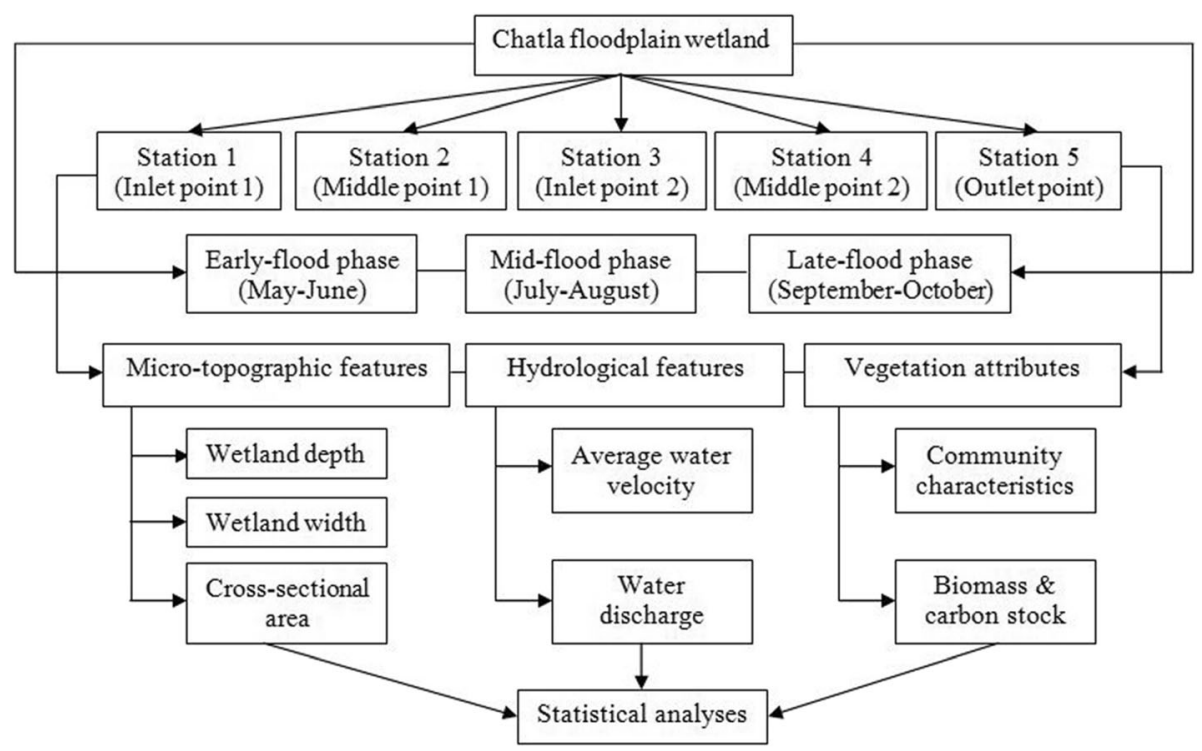

Fig. 3 Methodological framework of the present study 
$\times 1 \mathrm{~m}$ size laid in each sampling station during each flood phase for 2 years (Misra 1968). Overall, we sampled 90 quadrats during the entire study period. To minimize loss of below-ground plant parts, we excavated soil monoliths while uprooting the plant samples from each quadrat (Van der Maarel and Titlyanova 1989) in the littoral zone (within the partially submerged area to $2 \mathrm{~m}$ from the shoreline) in each sampling station. Subsequently, the plant samples were brought to the laboratory and washed with distilled water. The samples were segregated and labeled species-wise, and oven-dried at a temperature of $70{ }^{\circ} \mathrm{C}$ for $48 \mathrm{~h}$. The oven-dried samples were weighed using an electronic balance to determine the biomass of the individual plant species. We determined the total biomass of each species through the summation of the aboveground and below-ground biomass of the individuals of the respective species. For estimation of the carbon stock of the individual plant species, the corresponding biomass values of each species were multiplied with a conversion factor of 0.45 (Woomer 1999). The carbon stock values (g $\mathrm{m}^{-2}$ ) of the recorded plant species were multiplied by a factor of 0.01 to convert into Megagram per hectare $(\mathrm{Mg}$ $\left.\mathrm{ha}^{-1}\right)$. The total carbon stock $\left(\mathrm{Mg} \mathrm{ha}^{-1}\right)$ of the wetland vegetation for each station was estimated by summing up the carbon stock $\left(\mathrm{Mg} \mathrm{ha}^{-1}\right)$ values of all the plant species present in the respective stations.

\section{Statistical analysis}

Shapiro-Wilk test was done to check the normality of the data. One-way analysis of variance (ANOVA) was performed for normally distributed data while a KruskalWallis test was performed for non-normal data. ANOVA was performed to test the statistical significance of the variations in micro-topographic attributes such as depth, width, and cross-sectional area; flow parameters such as average water velocity and water discharge, and vegetation characters such as species richness, diversity indices, taxonomic distinctness and carbon stock of the wetland vegetation in different sampling stations and among the flood phases of the wetland. Tukey post-hoc analyses were performed to identify the dominant microtopographic attributes, water flow regime, and vegetation characters that created variations across different sampling stations. Kruskal-Wallis test was performed to assess the statistical significance of the variations in nonnormal variables such as density, IVI, and carbon stock of different species of wetland vegetation across different sampling stations. Multiple regression analysis was performed to study the effect of wetland micro-topography and water flow regime on vegetation carbon stock. All the statistical analyses were performed using SPSS software (version 20) (Nie et al. 2011). Canonical correspondence analysis (CCA) was performed to study the relationship between the plant species assemblages with micro-topographic conditions and water flow regime in the wetland using CANOCO software (version 4.5, Trial version) (Ter Braak and Smilauer 2002).

\section{Results}

\section{Species composition and diversity}

Overall, we recorded 36 species of lower groups of angiosperms comprising of 31 herbs and 5 shrubs, belonging to 16 families from the study area (Table 1). Poaceae represented by 14 species was the dominant family, followed by Cyperaceae with six species. Herbaceous species were more than shrubs across all the stations. However, when compared, the number of herbaceous species was higher in the inlet and outlet points compared to the middle points, and the reverse trend was observed for the shrubs. Overall family and species richness of wetland vegetation were higher in the inlet and outlet points as compared to the middle points (Table $1)$. However, the species richness did not vary significantly among the stations (Table 2).

On average, the Shannon-Wiener diversity index and Buzas \& Gibson's Evenness index were significantly higher in inlet and outlet points compared to the middle points, while the Simpson dominance index was significantly higher in middle points compared to other sites (Tables 1 and 2). One-way ANOVA revealed significant variations in all diversity indices across the sampling stations (Table 2). Tukey HSD post-hoc multiple comparisons test revealed significant differences in the mean values of Simpson dominance index and Buzas and Gibson's evenness index were between the station pair $2-3$, while significant differences in the mean values of Shannon-Wiener diversity index were observed between station pairs 2-3 and 2-4 (Table 3). The density of the Poaceae members was highest in all the stations and particularly in the inlet and outlet points. Following Poaceae, the density of Cyperaceae members was comparatively higher in the middle points (Additional file 1: Table S1). The average taxonomic distinctness of wetland vegetation was higher in the middle points as compared to the inlets and outlet points (Fig. 4a), though one-way ANOVA did not reveal significant differences in taxonomic distinctness among the stations (2). Cluster analyses of the wetland vegetation revealed two distinct groups, of which, one group comprised of vegetation across the inlet and outlet points of the wetland, while the other group comprised of vegetation across the middle points (Fig. 4b).

Species richness was significantly higher during the mid-flood phase and lowest during the late flood phase (Additional file 2: Figure S1a and Additional file 1: Table S2). Species diversity index was significantly higher during the early flood phase and lowest during the late flood phase (Additional file 2: Figure S1b, and Additional file 
Table 1 Distribution and diversity profile of vegetation in the wetland across different sampling stations

\begin{tabular}{|c|c|c|c|c|c|}
\hline Family and taxa & $\begin{array}{l}\text { Station } 1 \\
\text { (Inlet point 1) }\end{array}$ & $\begin{array}{l}\text { Station } 2 \\
\text { (Middle point 1) }\end{array}$ & $\begin{array}{l}\text { Station } 3 \\
\text { (Inlet point 2) }\end{array}$ & $\begin{array}{l}\text { Station } 4 \\
\text { (Middle point 2) }\end{array}$ & $\begin{array}{l}\text { Station } 5 \\
\text { (Outlet point) }\end{array}$ \\
\hline \multicolumn{6}{|l|}{ Amarathaceae } \\
\hline Alternanthera paronychioides A. St.-Hil & - & - & + & - & + \\
\hline Alternanthera sessilis (L.) R. Br.ex DC. & + & - & + & - & + \\
\hline \multicolumn{6}{|l|}{ Apiaceae } \\
\hline Centella asiatica (L.) Urb. & + & + & + & + & + \\
\hline \multicolumn{6}{|l|}{ Compositae } \\
\hline Centipeda minima (L.) A. Braun \& Asch. & - & - & - & - & + \\
\hline Eclipta prostrata (L.) L. & - & - & + & - & + \\
\hline \multicolumn{6}{|l|}{ Araceae } \\
\hline Colocasia esculenta (L.) Schott & + & - & - & - & - \\
\hline \multicolumn{6}{|l|}{ Arecaceae } \\
\hline Calamustenuis Roxb. & - & - & - & + & - \\
\hline \multicolumn{6}{|l|}{ Ceratophyllaceae } \\
\hline Ceratophyllum demersum L. & - & + & - & - & - \\
\hline \multicolumn{6}{|l|}{ Convolvulaceae } \\
\hline Ipomoea carnea Jacq. & + & + & + & - & + \\
\hline \multicolumn{6}{|l|}{ Cyperaceae } \\
\hline Cyperus haspan L. & - & + & - & - & - \\
\hline Cyperus javanicus Houtt. & - & + & - & - & - \\
\hline Cyperus compressus L. & - & - & + & - & + \\
\hline Eleocharis acicularis (L.) Roem. \& Schult. & - & - & - & + & - \\
\hline Fimbristylis bisumbellata (Forssk.) Bubani & - & + & - & + & + \\
\hline Fimbristylis littoralis Gaudich. & + & - & - & - & - \\
\hline \multicolumn{6}{|l|}{ Euphorbiaceae } \\
\hline Croton bonplandianus Baill. & - & - & - & + & - \\
\hline \multicolumn{6}{|l|}{ Marantaceae } \\
\hline Schumannianthus dichotomus (Roxb.) Gagnep. & - & + & - & - & - \\
\hline \multicolumn{6}{|l|}{ Melastomataceae } \\
\hline Melastoma malabathricum L. & - & + & - & - & - \\
\hline \multicolumn{6}{|l|}{ Onagraceae } \\
\hline Ludwigia hyssopifolia (G.Don) Exell & - & - & + & - & - \\
\hline \multicolumn{6}{|l|}{ Poaceae } \\
\hline Axonopus fissifolius (Raddi) Kuhlm. & - & - & - & + & - \\
\hline Brachiaria ramosa (L.) Stapf & + & - & + & - & - \\
\hline Chrysopogon aciculatus (Retz.) Trin. & + & - & + & + & - \\
\hline Chrysopogon zizanioides (L.) Roberty & + & + & + & + & + \\
\hline Cynodon dactylon (L.) Pers. & + & + & + & + & + \\
\hline Digitaria ciliaris (Retz.) Koeler & - & - & - & - & + \\
\hline Eleusine indica (L.) Gaertn. & + & - & - & - & - \\
\hline Eragrostis unioloides (Retz.) Nees ex Steud. & + & - & - & - & - \\
\hline Hemarthria compressa (L.f.) R.Br. & - & - & + & - & - \\
\hline Paspalum notatum Flüggé & + & - & - & - & + \\
\hline Paspalum scrobiculatum L. & - & + & - & - & - \\
\hline
\end{tabular}


Table 1 Distribution and diversity profile of vegetation in the wetland across different sampling stations (Continued)

\begin{tabular}{|c|c|c|c|c|c|}
\hline Family and taxa & $\begin{array}{l}\text { Station } 1 \\
\text { (Inlet point 1) }\end{array}$ & $\begin{array}{l}\text { Station } 2 \\
\text { (Middle point 1) }\end{array}$ & $\begin{array}{l}\text { Station } 3 \\
\text { (Inlet point 2) }\end{array}$ & $\begin{array}{l}\text { Station } 4 \\
\text { (Middle point 2) }\end{array}$ & $\begin{array}{l}\text { Station } 5 \\
\text { (Outlet point) }\end{array}$ \\
\hline Pseudoraphis spinescens (R.Br.) Vickery & - & + & + & - & - \\
\hline Saccharum ravennae (L.) L. & - & + & + & - & + \\
\hline Sacciolepis interrupta (Willd.) Stapf & + & - & - & - & - \\
\hline \multicolumn{6}{|l|}{ Polygonaceae } \\
\hline Persicaria hydropiper (L.) Delarbre & + & - & + & - & + \\
\hline \multicolumn{6}{|l|}{ Pontederiaceae } \\
\hline Eichhornia crassipes (Mart.) Solms & + & - & + & + & + \\
\hline \multicolumn{6}{|l|}{ Rubiaceae } \\
\hline Oldenlandia diffusa (Wild.) Roxb. & - & + & + & + & + \\
\hline Total family: 16 & Family (8) & Family (8) & Family (10) & Family (7) & Family (8) \\
\hline \multirow[t]{3}{*}{ Total taxa: 36} & Taxa (15) & Taxa (14) & Taxa (17) & Taxa (11) & Taxa (16) \\
\hline & Herb (14) & Herb (11) & Herb (16)Shrub (1) & Herb (9) & Herb (15) \\
\hline & Shrub (1) & Shrub (3) & & Shrub (2) & Shrub (1) \\
\hline \multirow[t]{3}{*}{ Shannon-Wiener Diversity index } & 1.14 & 1.18 & 0.68 & 0.65 & 1.08 \\
\hline & \pm 0.50 & \pm 0.06 & \pm 0.38 & \pm 0.44 & \pm 0.37 \\
\hline & $(0.49-1.56)$ & $(1.12-1.25)$ & $(0.22-1.23)$ & $(0.13-1.16)$ & $(0.73-1.53)$ \\
\hline \multirow[t]{3}{*}{ Simpson Dominance index } & 0.48 & 0.36 & 0.63 & 0.65 & 0.41 \\
\hline & \pm 0.27 & \pm 0.02 & \pm 0.19 & \pm 0.26 & \pm 0.13 \\
\hline & $(0.26-0.91)$ & $(0.33-0.39)$ & $(0.36-0.90)$ & $(0.34-0.95)$ & $(0.25-0.55)$ \\
\hline \multirow[t]{3}{*}{ Buzas and Gibson's Evenness index } & 0.54 & 0.51 & 0.40 & 0.45 & 0.53 \\
\hline & \pm 0.07 & \pm 0.06 & \pm 0.03 & \pm 0.17 & \pm 0.11 \\
\hline & $(0.41-0.60)$ & $(0.43-0.59)$ & $(0.35-0.43)$ & $(0.20-0.71)$ & $(0.41-0.70)$ \\
\hline
\end{tabular}

"-" represents an absence of the taxa concerned; total number of quadrats studied $=300$; for diversity indices mean \pm SD, $n=6$; values within parenthesis represent the range of the respective mean value

1: Table S2). However, the dominance and evenness indices and taxonomic distinctness did not vary significantly across the flood phases (Additional file 2: Figure S1c-e and Additional file 1: Table S2). The dominancediversity curve of the wetland vegetation revealed that during the flood phase, most of the resources of wetland were shared among few dominant species (Additional file 2: Figure S2), with Chrysopogon

Table 2 One-way analyses of variance showing variations in vegetation attributes in the wetland with sampling stations as the main effect variable

\begin{tabular}{ccc}
\hline Parameters & & F-statistic \\
\hline Species richness & & $1.113^{\text {ns }}$ \\
Diversity indices & Simpson dominance index & $3.684^{*}$ \\
& Shannon-Wiener diversity index & $3.295^{*}$ \\
& Buzas and Gibson's evenness index & $3.137^{*}$ \\
Taxonomic distinctness & $2.685^{\text {ns }}$ \\
Total C stock $\left(\mathrm{Mg} \mathrm{ha}^{-1}\right)$ & $0.962^{\text {ns }}$ \\
\hline
\end{tabular}

Degree of freedom $(n-1)=4$; ns non-significant

${ }^{* *} p<0.01$

${ }^{*} p<0.05$ zizanioidesas being the most dominant species in all the sampling stations (Additional file 1: Tables S3, S4).

\section{Spatial and temporal variations in micro-topography and water flow regime}

Depth was more in the inlet and outlet points of the wetland as compared to its middle points (Table 4). The wetland width and cross-sectional area were higher in the middle points as compared to the inlet and outlet points. One-way ANOVA revealed significant variations in the micro-topographic variables, namely, width, and crosssectional area across the sampling stations (Table 4). Tukey HSD post-hoc multiple comparison test revealed significant differences in the mean width between the station pairs 12, 1-4, 2-3, 2-5, 3-4, and 4-5 (Table 4). Similarly, significant differences in the cross-sectional area were observed between the station pairs 1-4, 3-4, and 4-5 (Table 4). The average water velocity and discharge were higher in the inlet and outlet points, whereas the values were very low (below detectable level) in the middle points (Table 4). One-way ANOVA revealed significant differences in the 
Table 3 Multiple comparisons of vegetation attributes in the wetland at different sampling stations using Tukey Post-hoc analysis

\begin{tabular}{|c|c|c|c|c|}
\hline \multicolumn{2}{|l|}{ Parameters } & \multirow{3}{*}{$\begin{array}{l}\text { Station } \\
(\text { (I) } \\
\text { Station } 1\end{array}$} & \multirow{2}{*}{$\begin{array}{l}\text { Station } \\
(J) \\
\text { Station } 2\end{array}$} & \multirow{2}{*}{$\begin{array}{l}\text { Mean difference } \\
(I-J) \\
0.17243^{\text {ns }}\end{array}$} \\
\hline \multirow{30}{*}{$\begin{array}{l}\text { Vegetation } \\
\text { attributes }\end{array}$} & \multirow{10}{*}{$\begin{array}{l}\text { Simpson } \\
\text { dominance index }\end{array}$} & & & \\
\hline & & & Station 3 & $-0.19695^{\mathrm{ns}}$ \\
\hline & & & Station 4 & $-0.16725^{\mathrm{ns}}$ \\
\hline & & & Station 5 & $0.07802^{\mathrm{ns}}$ \\
\hline & & Station 2 & Station 3 & $-0.36938^{*}$ \\
\hline & & & Station 4 & $-0.33968^{\mathrm{ns}}$ \\
\hline & & & Station 5 & $-0.09442^{\mathrm{ns}}$ \\
\hline & & Station 3 & Station 4 & $0.02970^{\text {ns }}$ \\
\hline & & & Station 5 & $0.27497^{\mathrm{ns}}$ \\
\hline & & Station 4 & Station 5 & $0.24527^{\text {ns }}$ \\
\hline & \multirow{10}{*}{$\begin{array}{l}\text { Shannon-Wiener } \\
\text { diversity index }\end{array}$} & Station 1 & Station 2 & $-0.33268^{\mathrm{ns}}$ \\
\hline & & & Station 3 & $0.37373^{\text {ns }}$ \\
\hline & & & Station 4 & $0.40460^{\text {ns }}$ \\
\hline & & & Station 5 & $-0.03017^{\mathrm{ns}}$ \\
\hline & & Station 2 & Station 3 & $0.70642^{*}$ \\
\hline & & & Station 4 & $0.73728^{*}$ \\
\hline & & & Station 5 & $0.30252^{\mathrm{ns}}$ \\
\hline & & Station 3 & Station 4 & $0.03087^{\mathrm{ns}}$ \\
\hline & & & Station 5 & $-0.40390^{\mathrm{ns}}$ \\
\hline & & Station 4 & Station 5 & $-0.43477^{\mathrm{ns}}$ \\
\hline & \multirow{10}{*}{$\begin{array}{l}\text { Buzas and Gibson's } \\
\text { evenness index }\end{array}$} & Station 1 & Station 2 & $-0.02285^{\mathrm{ns}}$ \\
\hline & & & Station 3 & $0.18023^{\mathrm{ns}}$ \\
\hline & & & Station 4 & $0.06898^{\text {ns }}$ \\
\hline & & & Station 5 & $-0.01743^{\mathrm{ns}}$ \\
\hline & & Station 2 & Station 3 & $0.20308^{*}$ \\
\hline & & & Station 4 & $0.09183^{\mathrm{ns}}$ \\
\hline & & & Station 5 & $0.00542^{\text {ns }}$ \\
\hline & & Station 3 & Station 4 & $-0.11125^{\mathrm{ns}}$ \\
\hline & & & Station 5 & $-0.19767^{\mathrm{ns}}$ \\
\hline & & Station 4 & Station 5 & $-0.08642^{\mathrm{ns}}$ \\
\hline
\end{tabular}

Station 1 = inlet point 1 ; station $2=$ middle point 2 ; station $3=$ inlet point 2 ; station $4=$ middle point 2 ; station $5=$ outlet point; degree of freedom $(n-1)$ $=4$

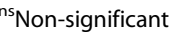

${ }^{*} p<0.05$

${ }^{* *} p<0.01$

water flow regime, namely water velocity and discharge among the sampling stations (Table 4). Tukey HSD posthoc comparisons test revealed significant differences in the mean values of water velocity and water discharge between the station pairs $1-2,1-4,2-3$, and 3-4 (Table 5).

Depth, width, cross-sectional area, and water discharge were highest during the mid-flood phase, while water velocity was highest during the early flood phase (Additional

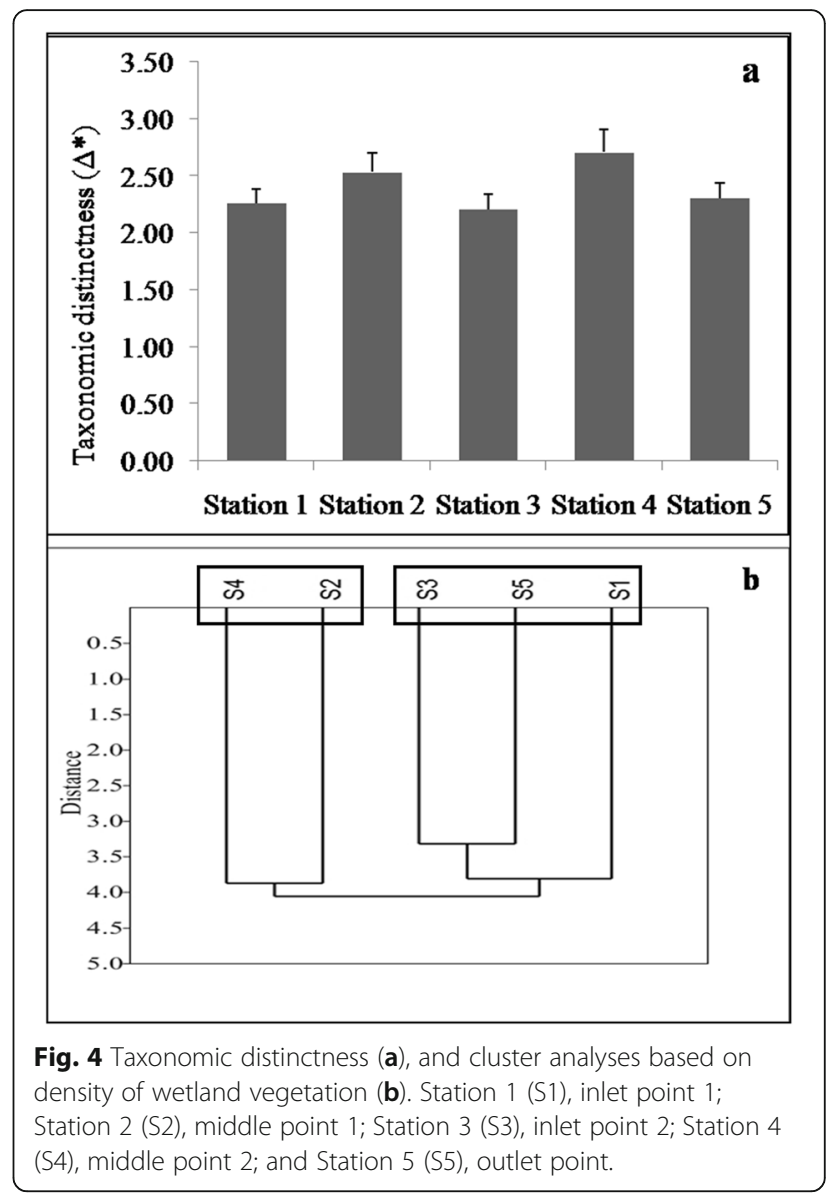

file 2: Figure $\mathrm{S} 3 \mathrm{a}-\mathrm{S} 3 \mathrm{e})$. Depth and water discharge were lowest during the late flood phase, while width and crosssectional area were lowest during the early flood phase. Only the water velocity was observed to be lowest during the mid-flood phase (Additional file 2: Figure S3d). The differences in the various parameters between various flood phases were statistically non-significant (Additional file 1: Table S2).

\section{Relationship of species assemblage with wetland micro- topography and water flow regime}

The CCA ordination plot revealed that most of the plant species assemblages were strongly associated with the micro-topography and water flow regime within the wetland (Fig. 5 and Table 6). The ordination plot revealed that species such as Brachiaria ramosa, Centella asiatica, and Colocasia esculenta were associated with depth, while Alternanthera paronychioides, Persicaria hydropiper, and Hemarthria compressa were associated with water velocity. Alternanthera sessilis, Digitaria ciliaris, and Eragrostis unioloides were associated with water discharge; Axonopus fissifolius, Eleocharis acicularis, and Calamus tenuis were associated with cross-sectional area, and Croton bonplandianus was associated with 
Table 4 Micro-topography and flow parameters in the wetland in different sampling stations; and, one-way analyses of variance showing variations in micro-topography and flow parameters in the wetland with sampling stations as the main effect variable

\begin{tabular}{|c|c|c|c|c|c|c|}
\hline Parameters & $\begin{array}{l}\text { Station } 1 \\
\text { (inlet point 1) }\end{array}$ & $\begin{array}{l}\text { Station } 2 \\
\text { (middle point 1) }\end{array}$ & $\begin{array}{l}\text { Station } 3 \\
\text { (inlet point 2) }\end{array}$ & $\begin{array}{l}\text { Station } 4 \\
\text { (middle point 2) }\end{array}$ & $\begin{array}{l}\text { Station } 5 \\
\text { (outlet point) }\end{array}$ & F-statistic \\
\hline $\begin{array}{l}\text { Depth } \\
\text { (m) }\end{array}$ & $\begin{array}{l}0.84 \pm 0.67 \\
(0.35-2.25)\end{array}$ & $\begin{array}{l}0.47 \pm 0.11 \\
(0.30-0.68)\end{array}$ & $\begin{array}{l}1.09 \pm 0.53 \\
(0.50-2.20)\end{array}$ & $\begin{array}{l}0.71 \pm 0.26 \\
(0.30-1.54)\end{array}$ & $\begin{array}{l}0.64 \pm 0.16 \\
(0.32-0.79)\end{array}$ & $2.556^{\mathrm{ns}}$ \\
\hline $\begin{array}{l}\text { Width } \\
\text { (m) }\end{array}$ & $\begin{array}{l}25.14 \pm 12.16 \\
(12-52)\end{array}$ & $\begin{array}{l}1217.50 \pm 1387.42 \\
(65-4050)\end{array}$ & $\begin{array}{l}13.31 \pm 6.27 \\
(8-25)\end{array}$ & $\begin{array}{l}1720 \pm 512.69 \\
(950-2500)\end{array}$ & $\begin{array}{l}20 \pm 8.87 \\
(10-38)\end{array}$ & $8.024^{* *}$ \\
\hline Cross-sectional area $\left(\mathrm{m}^{2}\right)$ & $\begin{array}{l}27.55 \pm 35.78 \\
(4.92-117)\end{array}$ & $\begin{array}{l}583.82 \pm 499.04 \\
(94.11-1091.71)\end{array}$ & $\begin{array}{l}17.12 \pm 17.41 \\
(6.89-37.23)\end{array}$ & $\begin{array}{l}1188.54 \pm 276.39 \\
(962.15-1496.55)\end{array}$ & $\begin{array}{l}13.30 \pm 7.60 \\
(5.33-20.50)\end{array}$ & $10.076^{* *}$ \\
\hline $\begin{array}{l}\text { Water velocity } \\
\left(\mathrm{m} \mathrm{s}^{-1}\right)\end{array}$ & $\begin{array}{l}0.34 \pm 0.22 \\
(0.05-0.76)\end{array}$ & $\mathrm{BDL}$ & $\begin{array}{l}0.32 \pm 0.21 \\
(0.10-0.72)\end{array}$ & $\mathrm{BDL}$ & $\begin{array}{l}0.19 \pm 0.07 \\
(0.10-0.30)\end{array}$ & $7.369^{* *}$ \\
\hline $\begin{array}{l}\text { Water discharge } \\
\text { (Cubic } \mathrm{m} \mathrm{s}^{-1} \text { ) }\end{array}$ & $\begin{array}{l}4.87 \pm 2.98 \\
(1.23-13.64)\end{array}$ & $\mathrm{BDL}$ & $\begin{array}{l}4.34 \pm 3.40 \\
(0.52-11.25)\end{array}$ & $\mathrm{BDL}$ & $\begin{array}{l}2.56 \pm 1.60 \\
(0.45-4.74)\end{array}$ & $7.369^{* *}$ \\
\hline
\end{tabular}

Mean \pm SD; $n=6$; values within parenthesis represent the range of the respective mean value; $B D L$ Below detectable limit; for F-statistic, degree of freedom ( $n-$

1) $=4$

${ }^{* *} p<0.01$

${ }^{*} p<0.05$

width (Fig. 5 and Table 6). Furthermore, species such as Cynodon dactylon, Eichhornia crassipes, Chrysopogon zizanioides that occurred in the middle of the ordination plot acted as generalists species.

\section{Effect of micro-topography and water flow regime on vegetation carbon stock}

The average carbon stock in wetland vegetation was higher in inlet and outlet points as compared to the middle points (Fig. 6, and Additional file 1: Table S4), though the variation was not significantly different among the sampling stations (Table 3). Flood phase wise variations in the vegetation carbon stock revealed significantly higher carbon stock during the mid-flood phase and lowest during the late flood phase (Additional file 2: Figure S4, and Additional file 1: Table S2). The multiple regression analysis for vegetation carbon stock against the micro-topographic and water flow regimes of wetland revealed a significant positive relationship of the vegetation carbon stock with the water discharge (Table 7, and Additional file 1: Table S5 and S6).

\section{Discussion}

Studying the relationship between topography and flow variation in wetlands is important as it has profound implications on its ecological functionality (Håkanson 1981; Sperling 1999; Nõges 2009; Stefanidis and Papastergiadou 2012). The present study revealed substantial variations in the water flow regime characterized by average water velocity and discharge across the sampling stations. We attribute these to the variations in the wetland microtopographic characteristics such as depth, width, and crosssectional area in the sampling stations across the wetland. Several other studies have also inferred that the topographic characteristics of aquatic ecosystems are among the significant determinants of flow variation (Wetzel 2001; Camila de Sousa et al. 2011; Yunus et al. 2003; Singh et al. 2014; Pandi et al. 2017; Soni 2017; Prabhakaran and Raj 2018), which in turn create heterogeneous micro-environments within wetlands.

Habitat heterogeneity created due to varying topographic and hydrologic characteristics generally determine the growth and distribution of aquatic vegetation (Ward et al. 1999; Bendix and Hupp 2000; Van Der Valk 2005; Camporeale and Ridolfi 2006). Such variations facilitate the plant species to colonize, co-exist, and proliferate (Dahlberg 2016; Larkin 2016; Schneider et al. 2018). This is evident in our study, where varying environmental condition putatively resulted in differential species assemblage pattern. For instance, the vegetation analysis revealed distinct species assemblage patterns in the stations with different micro-topographic parameters and water flow conditions. The CCA ordination plot revealed that species such as Alternanthera paronychioides, Alternanthera sessilis, Brachiaria ramosa, Eclipta prostrata, Hemarthria compressa, and Persicaria hydropiper were abundant in the inlet and outlet points of the wetland, which had greater depth. On the other hand, species such as Calamus tenuis, Ceratophyllum demersum, Eleocharis acicularis, Melastoma malabathricum, Pseudoraphis spinescens, and Schumannianthus dichotomus were abundant in the middle points which had greater cross-sectional area. However, species such as Chrysopogon aciculatus, Chrysopogon zizanioides, Cynodon dactylon, Fimbristylis bisumbellata, Ipomoea carnea, and Saccharum ravennae were recorded in inlet, middle, and outlet points with varying microtopographic attributes, and water flow regime.

The effect of habitat-related factors on species assemblage pattern is also reflected in the cluster diagram where the vegetation across the inlet and outlet points formed one cluster, while those across the middle points 
Table 5 Multiple comparisons of the micro-topography, and flow parameters in the wetland at different sampling stations using Tukey Post-hoc analysis

\begin{tabular}{|c|c|c|c|c|}
\hline Parameters & & $\begin{array}{l}\text { Station } \\
\text { (I) }\end{array}$ & $\begin{array}{l}\text { Station } \\
(J)\end{array}$ & $\begin{array}{l}\text { Mean difference } \\
(I-J)\end{array}$ \\
\hline \multirow[t]{20}{*}{ Micro-topography } & \multirow{10}{*}{$\begin{array}{l}\text { Width } \\
(\mathrm{m})\end{array}$} & \multirow[t]{4}{*}{ Station 1} & Station 2 & $-1192.36^{*}$ \\
\hline & & & Station 3 & $11.83^{\text {ns }}$ \\
\hline & & & Station 4 & $-1694.86^{* *}$ \\
\hline & & & Station 5 & $5.14^{\mathrm{ns}}$ \\
\hline & & \multirow[t]{3}{*}{ Station 2} & Station 3 & $1204.19^{*}$ \\
\hline & & & Station 4 & $-502.49^{\mathrm{ns}}$ \\
\hline & & & Station 5 & $1197.50^{*}$ \\
\hline & & \multirow[t]{2}{*}{ Station 3} & Station 4 & $-1706.69^{* *}$ \\
\hline & & & Station 5 & $-6.69^{\text {ns }}$ \\
\hline & & Station 4 & Station 5 & $1699.99 * *$ \\
\hline & \multirow{10}{*}{$\begin{array}{l}\text { Cross-sectional area } \\
\left(\mathrm{m}^{2}\right)\end{array}$} & \multirow[t]{4}{*}{ Station 1} & Station 2 & $-559.36^{\mathrm{ns}}$ \\
\hline & & & Station 3 & $2.49^{\mathrm{ns}}$ \\
\hline & & & Station 4 & $-1163.91^{* *}$ \\
\hline & & & Station 5 & $-9.83^{\mathrm{ns}}$ \\
\hline & & \multirow[t]{3}{*}{ Station 2} & Station 3 & $561.86^{\mathrm{ns}}$ \\
\hline & & & Station 4 & $-604.55^{\mathrm{ns}}$ \\
\hline & & & Station 5 & $549.53^{\mathrm{ns}}$ \\
\hline & & \multirow[t]{2}{*}{ Station 3} & Station 4 & $-1166.41^{* *}$ \\
\hline & & & Station 5 & $-12.33^{\mathrm{ns}}$ \\
\hline & & Station 4 & Station 5 & $1154.09^{* *}$ \\
\hline \multirow[t]{20}{*}{ Water flow regime } & \multirow{10}{*}{$\begin{array}{l}\text { Water velocity } \\
\left(\mathrm{m} \mathrm{s}^{-1}\right)\end{array}$} & \multirow[t]{4}{*}{ Station 1} & Station 2 & $0.33833^{*}$ \\
\hline & & & Station 3 & $0.01500^{\mathrm{ns}}$ \\
\hline & & & Station 4 & $0.33833^{*}$ \\
\hline & & & Station 5 & $0.15000^{\mathrm{ns}}$ \\
\hline & & \multirow[t]{3}{*}{ Station 2} & Station 3 & $-0.32333^{*}$ \\
\hline & & & Station 4 & $0.00000^{\mathrm{ns}}$ \\
\hline & & & Station 5 & $-0.18833^{n s}$ \\
\hline & & \multirow[t]{2}{*}{ Station 3} & Station 4 & $0.32333^{*}$ \\
\hline & & & Station 5 & $0.13500^{\mathrm{ns}}$ \\
\hline & & Station 4 & Station 5 & $-0.18833^{\mathrm{ns}}$ \\
\hline & \multirow{10}{*}{$\begin{array}{l}\text { Water discharge } \\
\left(\text { Cubic } \mathrm{m} \mathrm{s}^{-1} \text { ) }\right.\end{array}$} & \multirow[t]{4}{*}{ Station 1} & Station 2 & $4.87168^{*}$ \\
\hline & & & Station 3 & $0.52857^{\mathrm{ns}}$ \\
\hline & & & Station 4 & $4.87168^{*}$ \\
\hline & & & Station 5 & $2.31704^{\mathrm{ns}}$ \\
\hline & & \multirow[t]{3}{*}{ Station 2} & Station 3 & $-4.34311^{*}$ \\
\hline & & & Station 4 & $0.00000^{\mathrm{ns}}$ \\
\hline & & & Station 5 & $-2.55463^{\mathrm{ns}}$ \\
\hline & & \multirow[t]{2}{*}{ Station 3} & Station 4 & $4.34311^{*}$ \\
\hline & & & Station 5 & $1.78847^{\mathrm{ns}}$ \\
\hline & & Station 4 & Station 5 & $-2.55463^{\mathrm{ns}}$ \\
\hline
\end{tabular}

Station $1=$ inlet point 1, station $2=$ middle point 2 , station $3=$ inlet point 2 , station $4=$ middle point 2 ; station $5=$ outlet point, degree of freedom $(n-1)=4$; $n$ s $=$ non-significant

${ }^{*} p<0.05$

${ }^{* *} p<0.01$ 


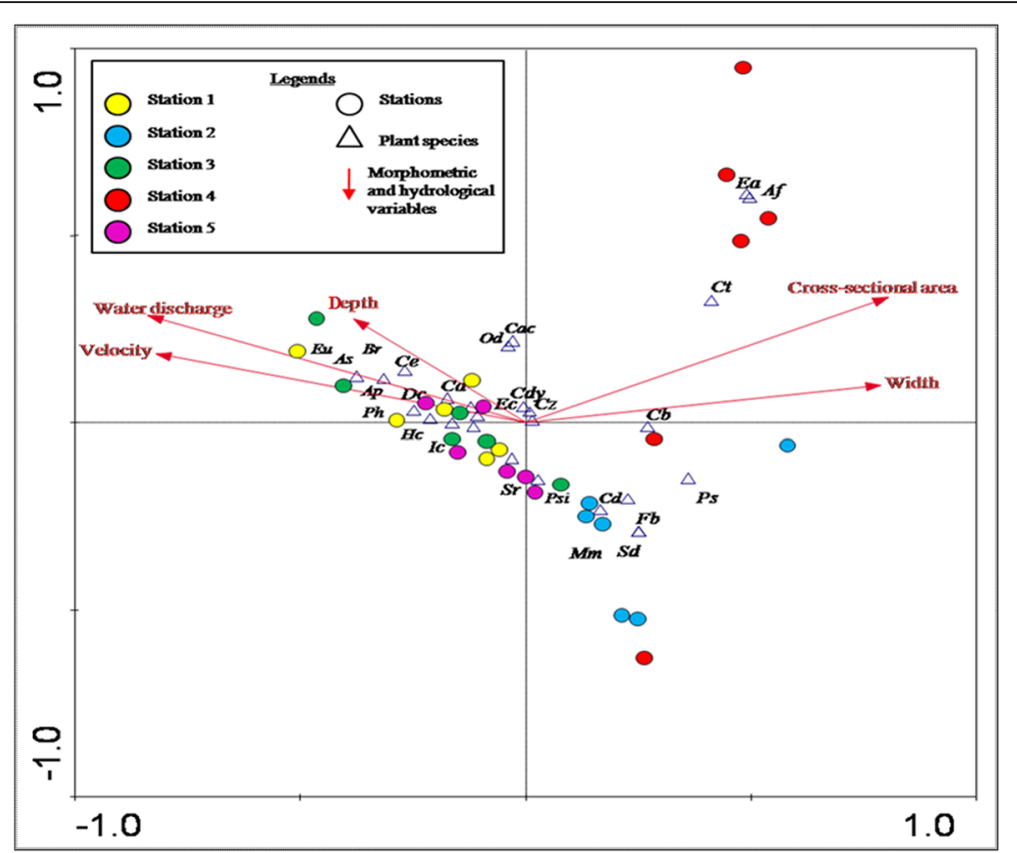

Fig. 5 Ordination plot of CCA elucidating the influence of micro-topography and flow regime on species assemblages. Abbreviations: Af Axonopus fissifolius, Ap Alternanthera paronychioides, As Alternanthera sessilis, Br Brachiaria ramosa, Ca Centella asiatica, Cac Chrysopogon aciculatus, $\mathrm{Cb}$ Croton bonplandianus, Cd Ceratophyllum demersum, Cdy Cynodon dactylon, Ce Colocasia esculenta, Ct Calamus tenuis, Cz Chrysopogon zizanioides, Dc Digitaria ciliaris, Ea Eleocharis acicularis, Ec Eichhornia crassipes, Eu Eragrostis unioloides, Fb Fimbristylis bisumbellata, Hc Hemarthria compressa, Ic Ipomoea carnea, Mm Melastoma malabathricum, Od Oldenlandia diffusa, Ph Persicaria hydropiper, Ps Paspalum scrobiculatum, Psi Pseudoraphis spinescens, Sd Schumannianthus dichotomus, Sr Saccharum ravennae

formed another cluster. The heterogeneous conditions in the inlet and outlet points due to greater water discharge and the associated change in the microhabitat condition in the presence of available resources from the tributaries plausibly allowed the maximum number of species to co-exist in those stations (Friedman and Auble 2000; Peralta et al. 2006). Consequently, the diversity of wetland plants was higher in inlet and outlet points of the wetland. On the other hand, lower diversity index of wetland vegetation in middle points can be attributed to limited resource due to low flow velocity and higher cross-sectional area, which facilitated only a few dominant species like Chrysopogon zizanioides and Cynodon dactylon to survive (Friedman and Auble 2000; Wright et al. 2015). However, no significant differences in species richness

Table 6 Results of canonical correspondence analysis (CCA) showing the strength of the species-environment relationship in the selected stations of the wetland

\begin{tabular}{lllll}
\hline & Axis 1 & Axis 2 & Axis 3 & Axis 4 \\
\hline Eigen values & 0.358 & 0.281 & 0.167 & 0.08 \\
$\begin{array}{l}\text { Species-environment correlations } \\
\begin{array}{l}\text { Cumulative percentage variance } \\
\text { of species data }\end{array}\end{array}$ & 0.916 & 0.803 & 0.832 & 0.61 \\
$\begin{array}{l}\text { Cumulative percentage variance } \\
\text { of species-environment relation }\end{array}$ & 38.3 & 21.9 & 27.7 & 30.4 \\
\hline
\end{tabular}

among the sampling stations might be due to the high levels of disturbance that prevented occurrence of most species, preventing coexistence and reducing species richness (Sharpe and Baldwin 2009). On the other hand, flood phase wise, lowest species richness and diversity in the late flood phase of the wetland can be attributed to the increased nutrient loss and tissue damage of wetland vegetation due to increased disturbance as a result of increased flood fluctuation frequency (Bornette et al. 2008).

Plant species diversity and assemblage are intricately linked with various ecological processes like ecosystem productivity (Naeem et al. 1996; Hector et al. 1999), retention of nutrients (Ewel et al. 1991), ecosystem stability, and resilience (Tilman and Downing 1994; Tilman et al. 2006). Assemblages with richer functional groups enhance ecosystem functioning facilitated through species-specific traits (Balvanera et al. 2006; Sullivan et al. 2007). In the context of the present study, variation in the carbon stock of the wetland vegetation can be linked to species-specific traits such as leaf area index, leaf carbon concentration, higher root biomass (Rawat et al. 2015), and an extensive network of the root system (Chomchalow 2001; Lavania et al. 2016). All these result in rapid growth and high biomass accumulation, which influence ecosystem carbon input (Tang et al. 2018). As evident from our results, the diversity and assemblage of such species varied under varying water flow 


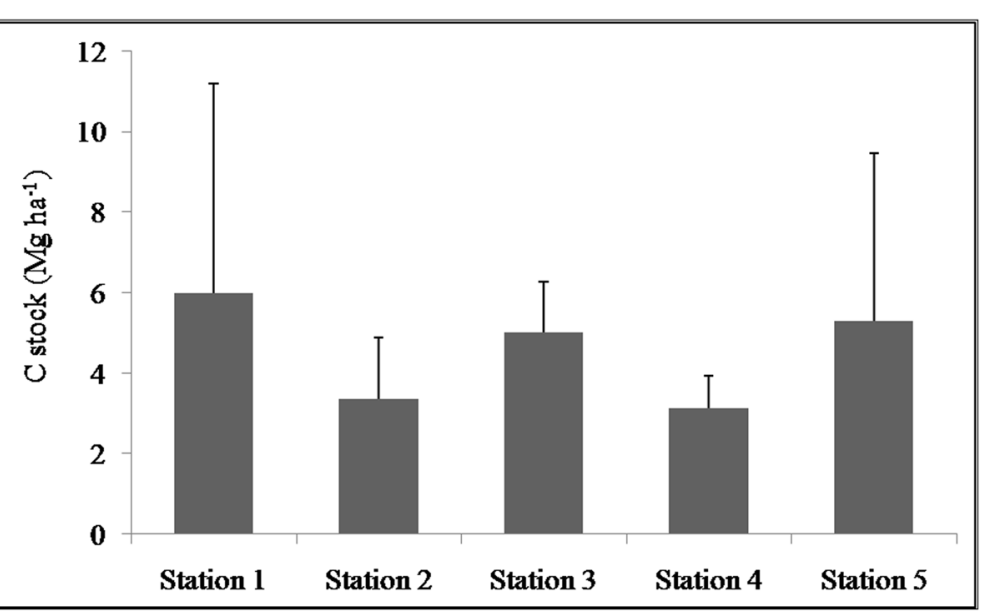

Fig. 6 Carbon stock $\left(\mathrm{Mg} \mathrm{ha}^{-1}\right)$ of wetland vegetation across the different sampling stations namely station 1, inlet point 1; station 2, middle point 1; station 3, inlet point 2; station 4, middle point 2; and station 5, outlet point

regime and micro-topographic conditions. For example, species such as Calamus tenuis, Schumannianthus dichotomus, and Melastoma malabathricum growing abundantly in the middle points of the wetland have several adaptive traits such as greater plant height, higher leaf area and rate of seed production (Faravani and Bakar 2007), while the other species such as Alternanthera sessilis, Eclipta prostrata, Hemarthria compressa, and Persicaria hydropiper growing profusely in the inlet and outlet points have adaptive traits such as production of dense mats of extremely fine adventitious/ superficial roots adapted for diverse range of moisture conditions that helped them in surviving under the given environmental conditions (Sultan 1995). The higher vegetation carbon stock in the inlet and outlet points compared to the middle points is, therefore, a result of the species adaptive response to the sitespecific environmental condition.

Our study indicates that small-scale seasonal wetlands have the potential to mitigate the impact of climate change at a regional level by sequestering substantial amounts of carbon in the vegetation component. This is evident from our findings, which revealed that the vegetation stocked about $4.56 \mathrm{Mg} \mathrm{C}^{-1}$ in the Chatla wetland, which is higher than the East Kolkata wetlands in India (2.48 $\mathrm{Mg} \mathrm{C} \mathrm{ha}^{-1}$, Pal et al. 2017). We have also elucidated that the vegetation carbon stock in wetlands is influenced by the micro-topography and flow regime, which determines the species assemblage pattern in wetlands. Therefore, any change in the wetland micro-topography and flow regime within wetlands putatively lead to a shift in the plant species assemblage pattern within the wetland, thus upsetting the process of carbon sequestration. Currently, floodplain wetlands cover $\sim 6 \%$ of the global land area, of which nearly $89 \%$ area is not protected (Reis et al. 2017). In Asia alone, $\sim 5000 \mathrm{~km}^{2}$ of wetland area are lost annually due to anthropogenic factors such as agricultural expansion and dam construction (McAllister et al. 2001). Other factors leading to wetland degradation and loss around the world include urbanization, developmental activities, agricultural runoff, discharge of polluted industrial effluents, and climate change (Bassi et al. 2014). Such an unprecedented loss in the area of the wetlands may have a significant impact on their capacity to provide important ecological services that also include regulation of regional climate (Zedler and Kercher 2005).

\section{Conclusion}

We conclude that variations in micro-topographic factor like cross-sectional area and water flow regime like water velocity together govern the carbon stocking potential of the vegetation in seasonal floodplain wetlands. Thus, we

Table 7 Results of multiple regression analysis (using backward method) for carbon stock in wetland vegetation against the microtopography and water flow regime in the wetland

\begin{tabular}{|c|c|c|c|c|c|c|c|c|}
\hline \multirow[t]{2}{*}{ Dependent variable } & \multirow[t]{2}{*}{ Predictor variable } & \multicolumn{2}{|c|}{$\begin{array}{l}\text { Unstandardized } \\
\text { Coefficients }\end{array}$} & \multirow{2}{*}{$\begin{array}{l}\text { Standardized Coefficients } \\
\text { Beta }\end{array}$} & \multirow[t]{2}{*}{$t$} & \multirow[t]{2}{*}{ Sig. } & \multicolumn{2}{|c|}{$\begin{array}{l}95.0 \% \text { Confidence } \\
\text { Interval for B }\end{array}$} \\
\hline & & $\bar{B}$ & Std. Error & & & & Lower Bound & Upper Bound \\
\hline \multirow[t]{2}{*}{ Carbon stock (Mg ha $\left.{ }^{-1}\right)$} & (Constant) & 3.334 & 0.663 & & 5.026 & 0.000 & 1.975 & 4.692 \\
\hline & Water discharge $\left(\mathrm{m}^{3} \mathrm{~s}^{-1}\right)$ & 0.520 & 0.181 & 0.478 & 2.876 & 0.008 & 0.150 & 0.891 \\
\hline
\end{tabular}


envisage that alteration of the micro-topography and flow in the tropical floodplain wetlands through anthropogenic activities such as quarrying, mining, impoundments, and landfills might affect the natural integrity of wetlands, leading to change in the plant species assemblages. Such changes in species assemblages might affect the carbon stocking potential of the wetlands, thereby affecting their role in providing valuable ecosystem services.

India has been a signatory to the Ramsar Convention on Wetlands as well as the Convention on Biological Diversity since the years 1986 and 1994, respectively (https:// www.ramsar.org, https://www.cbd.int). However, efforts on conservation and judicious use of wetlands in the country still need to gain momentum, as only 115 wetlands have garnered attention under the wetland conservation programs like National Wetland Conservation Programme (http://www.moef.nic.in). Mainly, small-scale wetlands are under severe threat due to landfilling/reclamation and are primarily neglected (Bassi et al. 2014), though they perform essential ecological functions as evidenced through the present study. Therefore, we recommend that the national level programs must also focus on documentation, restoration, and conservation of smallscale seasonal wetlands that are providing valuable ecological services and playing a crucial role in regional climate change mitigation. In the present study, we have drawn the conclusions based on observations made in a single seasonal floodplain wetland, which may be a limitation from the perspective of representativeness of similar ecosystems in the tropics. Therefore, we strongly recommend that future studies should focus on diverse wetland types with contrasting morphometric and hydrological characteristics to understand the varied effect of hydrogeomorphic settings on the vegetation carbon stock and thus, the carbon stocking capacity of wetlands under different micro-climatic conditions.

\section{Supplementary information}

Supplementary information accompanies this paper at https://doi.org/10. 1186/s13717-019-0201-9.

Additional file 1: Table S1. Distribution and density (no. of individuals $\mathrm{ha}^{-1}$ ) of vegetation across various sampling stations of the wetland and Kruskal-Wallis test with habitat conditions under different sampling stations as the main effect variable; Table S2. One-way analyses of variance for micro-topography, water flow regime and vegetation attributes in the wetland with flood phases as the main effect variable; Table S3. Importance Value Index (IVI) of vegetation across various sampling stations of the wetland and Kruskal-Wallis test with habitat conditions under different sampling stations as the main effect variable; Table S4. Carbon stock $\left(\mathrm{Mg} \mathrm{ha}^{-1}\right)$ of vegetation in different sampling stations of the wetland and Kruskal-Wallis test with habitat conditions under different sampling stations as the main effect variable; Table S5. Detailed results of multiple regression analysis (using backward method) for carbon stock in wetland vegetation against the micro-topographic parameters and water flow regime of the wetland; Table S6. Excluded variables in the multiple regression analysis (using backward method) for carbon stock in wetland vegetation against the micro-topographic and water flow regime of the wetland.

Additional file 2: Figure S1. Flood-phase wise variations in species richness (a), Shannon-Wiener diversity index (b), Simpson dominance index (c), Buzas and Gibson's evenness index (d), and Taxonomic distinctness (e) of the wetland vegetation; Figure S2. Flood phase wise dominancediversity curve of wetland vegetation in different sampling stations; aEarly flood phase, b- Mid-flood phase, c- Late flood phase; Station 1- inlet point 1; Station 2- middle point 1; Station 3-inlet point 2; Station 4- middle point 2 and Station 5- outlet point; Figure S3. Flood-phase wise variations in micro-topography and water flow regime of the wetland; depth (a), width (b), cross-sectional area (c), water velocity (d), and water discharge (e); Figure S4. Flood-phase wise variations in carbon stock in wetland vegetation

\section{Acknowledgements}

Authors acknowledge the RS-GIS lab of Aaranyak, Assam, for providing laboratory facilities for preparing the study area map. The first author is thankful to UGC, New Delhi, for providing the UGC-BSR fellowship in carrying out the research work.

\section{Authors' contributions}

All the authors contributed equally in the study design, data analysis, and preparation of the manuscript. All authors read and approved the final manuscript.

\section{Funding}

The corresponding author works as Assistant Professor in the Department of Ecology and Environmental Science, Assam University, Silchar, India. The first author is doing her PhD under the corresponding author in the same department and is supported by the UGC-BSR Fellowship. The third author works as a Research Associate in the Department of Botany, North-Eastern Hill University, Shillong, India.

\section{Availability of data and materials}

Available as supplementary information. The datasets supporting the conclusions of this article are included within the article and its additional files.

Ethics approval and consent to participate

Not applicable

\section{Consent for publication}

Not applicable

\section{Competing interests}

The authors declare that they have no competing interests.

\section{Author details}

${ }^{1}$ Department of Ecology and Environmental Science, Assam University, Silchar 788011, India. Department of Botany, North-Eastern Hill University, Shillong 793022, India.

Received: 5 July 2019 Accepted: 29 October 2019

Published online: 06 December 2019

\section{References}

Adame MF, Santini NS, Tovilla C, Vázquez-Lule A, Castro L, Guevara M (2015) Carbon stocks and soil sequestration rates of tropical riverine wetlands. Biogeosciences 12:3805-3818 https://doi.org/10.5194/bg-12-3805-2015

Adhikari S, Bajracharaya RM, Sitaula BK (2009) A review of carbon dynamics and sequestration in wetlands. J Wetl Ecol 2:42-46 https://doi.org/10.3126/jowe. V2i1.1855

Balvanera P, Pfisterer AB, Buchmann N, He JS, Nakashizuka T, Raffaelli D, Schmid B (2006) Quantifying the evidence for biodiversity effects on ecosystem functioning and services. Ecol Lett 9:1146-1156 https://doi.org/10.1111/j. 1461-0248.2006.00963.x

Bassi N, Kumar MD, Sharma A, Pardha-Saradhi P (2014) Status of wetlands in India: a review of extent, ecosystem benefits, threats and management 
strategies. J Hydrol Reg Stud 2:1-19 https://doi.org/doi:10.1016/j.ejrh.2014.07. 001

Bendix J, Hupp CR (2000) Hydrological and geomorphological impacts on riparian plant communities. Hydrol Process 14:2977-2990. https://doi.org/10. 1002/1099-1085(200011/12)14:16/17 < 2977::AID-HYP130 > 3.0.CO;2-4.

Bernal B, Mitsch WJ (2013) Carbon sequestration in freshwater wetlands in Costa Rica and Botswana. Biogeochemistry 115:77-93 https://doi.org/10.1007/ s10533-012-9819-8

Bornette G, Tabacchi E, Hupp C, Puijalon S, Rostan JC (2008) A model of plant strategies in fluvial hydrosystems. Freshw Biol 53:1692-1705

Buzas MA, Gibson TG (1969) Species diversity: benthonic foraminifera in Western North Atlantic. Science 163:72-75 https://doi.org/10.1126/science.163.3862.72

Camila de Sousa L, de Barros Correa AC, do Nascimento NR (2011) Analysis of the morphometric parameters of the Rio Preto basin, Serra do Espinhaço (Minas Gerais, Brazil). Geosciences $=$ Geociências 30:05-112

Camporeale C, Ridolfi L (2006) Riparian vegetation distribution induced by river flow variability: a stochastic approach. Water Resour Res 42:W10415.https:// doi.org/10.1029/2006WR004933.

Carnell PE, Windecker SM, Brenker M, Baldock J, Masque P, Brunt K, Macreadie PI (2018) Carbon stocks, sequestration, and emissions of wetlands in south eastern Australia. Glob Chang Biol 24:4173-4184 https://doi.org/10.1111/gcb. 14319

Cherry JA (2011) Ecology of Wetland Ecosystems: Water, Substrate, and Life. Nature Educat Knowl 3:16

Chomchalow N (2001)The utilization of Vetiver as medicinal and aromatic plants with special reference to Thailand. Tech. Bull. No. 2001/1, PRVN / ORDPB, Bangkok, Thailand.

Cierjacks A, Kleinschmit B, Babinsky M, Kleinschroth F, Markert A, Menzel M, Ziechmann U, Schiller T, Graf M, Lang F (2010) Carbon stocks of soil and vegetation on Danubian floodplains. J Plant Nutr Soil Sci 173:644-653 https://doi.org/10.1002/jpln.200900209

Clarke KR, Warwick RM (1998) A taxonomic distinctness index and its statistical properties. J Appl Ecol 35:523-531 https://doi.org/10.1046/j.1365-2664.1998. 3540523.x

Conner WH, Day Jr JW (1982) Ecology of forested wetlands in the southeastern United States. In: Gopal B (ed) Wetlands ecology and management: Proceedings of First International Wetlands Conference, New Delhi, India, 1017 September 1980.

Costanza R, d'Arge R, de Groot R, Farber S, Grasso M, Hannon B, Limburg K, Naeem S, O'neill RV, Paruelo J, Raskin RG (1997) The value of the world's ecosystem services and natural capital. Nature 387:253-260. https://doi.org/ $10.1038 / 387253 a 0$

Craft C, Vymazal J, Kröpfelová L (2018) Carbon sequestration and nutrient accumulation in floodplain and depressional wetlands. Ecol Eng 114:137-145. https://doi.org/10.1016/j.ecoleng.2017.06.034 0925-8574.

Dahlberg CJ (2016) The role of microclimate for the performance anddistribution of forest plants. Stockholm University, Dissertation

Elosegi A, Díez J, Mutz M (2010) Effects of hydromorphological integrity on biodiversity and functioning of river ecosystems. Hydrobiologia 657:199-215 https://doi.org/10.1007/s10750-009-0083-4

Ewel JJ, Mazzarino MJ, Berish CW (1991) Tropical soil fertility changes under monocultures and successional communities of different structure. Ecol Appl 1:289-302

Faravani M, Bakar BB (2007) Effects of light on seed germination, growth pattern of straits Rhododendron (Melastoma malabathricum L.). J Agricul Biol Sci 2:1-5

Friedman JM, Auble GT (2000) Floods, flood control, and bottomland vegetation. Inland Flood Hazards: Human, Riparian, and Aquatic Communities. Cambridge University Press, Cambridge, UK.

Gordon ND, McMahon TA, Finlayson BL, Gippel CJ (2004) Stream hydrology: an introduction for ecologists. John Wiley and Sons, New York

Håkanson L (1981) A manual of lake morphometry. Springer-Verlag, New York

Hammer $\varnothing$ (eds) (2011) Past paleontological statistics, Version 3.14: Reference Manual. Natural History Museum, University of Oslo, Norway.

Hector A, Schmid B, Beierkuhnlein C, Caldeira MC, Diemer M, Dimitrakopoulos PG, Finn JA, Freitas H, Giller PS, Good J, Harris R (1999) Plant diversity and productivity experiments in European grasslands. Science 286:1123-1127

Kanjilal UN, Kanjilal PC, Das A (1934) Flora of Assam, Vol 1. Government of Assam, Assam

Kanjilal UN, Kanjilal PC, Das A (1936) Flora of Assam, Vol 2. Government of Assam, Shillong
Kanjilal UN, Kanjilal PC, Das A, De RN (1938) Flora of Assam, Vol 3. The Authority of the Government of Assam

Kanjilal UN, Kanjilal PC, De RN, Das A (1940) Flora of India, Vol 4. Government of Assam, Shillong

Kar D, Barbhuiya AH, Saha B (2008) Wetland diversity of Assam: their present status. In: Sengupta M, Dalwani R (eds) Proceedings of Taal 2007: The 12th world lake conference: 1844-1857, Jaipur (Rajasthan)

Karume K, Bagalwa M, Yalire M, Kazi K, BagulaEM BR, Nahayo D, Kasangaki A, Byamukama J (2016) Hydrological systems in the Greater Virunga Landscape: water quality around Mikeno Sector. J Water Resour Protec 8:382 https://doi. org/10.4236/jwarp.2016.83032

Kent M (2011) Vegetation Description and Data Analysis: A Practical Approach. 2nd edition, Wiley-Blackwell, Chichester.

Kolka RK, Murdiyarso D, Kauffman JB, Birdsey RA (2016) Tropical wetlands, climate, and land-use change: adaptation and mitigation opportunities. Wet Ecol Manage 24:107-112 https://doi.org/10.1007/s11273-016-9487-x

Krebs CJ (1989) Ecological methodology (No. QH541. 15. S72. K74 1999). Harper \& Row, New York, USA.

Kumar MD, Patel A, Ravindranath R, Singh OP (2008) Chasing a mirage: water harvesting and artificial recharge in naturally water-scarce regions. Econ Polit Wkly 30:61-71

Lacoul P, Freedman B (2006) Environmental influences on aquatic plants in freshwater ecosystems. Environ Rev 14:89-136

Larkin DJ (2016) Wetland heterogeneity. The wetland book: I: Structure and function, management and methods. Springer Netherlands.

Lavania UC, Rai SK, Lavania S, Basu S, Dubey BK, Ujagir R (2016) Autotetraploid Vetiveria zizaniodes plant useful for carbon sequestration and soil conservation named 'CIMAP-KH 40', U.S. Patent Application 13/506,598.

McAllister DE, Craig JF, Davidson N, Delany S, Seddon M (2001) Biodiversity impacts of large dams, International Union for Conservation of Nature and United Nations Environmental Programme, Gland, Switzerland and Nairobi, Kenya.

McLaughlin DL, Cohen MJ (2013) Realizing ecosystem services: wetland hydrologic function along a gradient of ecosystem condition. Ecol Appl 23: 1619-31

Misra R (1968) Ecology Workbook. Oxford \& IBH Publishing Co, Calcutta

Mitra S, Wassmann R, Vlek PL (2005) An appraisal of global wetland area and its organic carbon stock. Curr Sci 88:25-35

Mitsch WJ, Gosselink JG (2015) Wetlands. fifth edn. Wiley: Hoboken, New Jersy

Murphy KJ, Dickinson G, Thomaz SM, Bini LM, Dick K, Greaves K, Kennedy MP, Livingstone S, McFerran H, Milne JM, Oldroyd J (2003) Aquatic plant communities and predictors of diversity in a sub-tropical river floodplain: the upper Rio Paraná, Brazil. Aquat Bot 77:257-276.https://doi.org/10.1016/S03043770(03)00108-6

Naeem S, Thompson L, Lawler SP, Lawton JH, Woodfin RM (1996) Biodiversity and plant productivity in model assemblage of plant species. Oikos 76:259264

Neue HU, Gaunt JL, Wang ZP, Becker-Heidmann P, Quijano C (1997) Carbon in tropical wetlands. Geoderma 79:163-185.https://doi.org/10.1016/S00167061(97)00041-4.

Nie N, Hull C, Bent D (2011) IBM statistical package for the social sciences (SPSS Version 20). Computer Software. Chicago, IL: SPSS.

Nõges T (2009) Relationships between morphometry, geographic location and water quality parameters of European lakes. Hydrobiologia 633:33-43 https:// doi.org/10.1007/s10750-009-9874-x

Pal S, Chattopadhyay B, Datta S, Mukhopadhyay SK (2017) Potential of wetland macrophytes to sequester carbon and assessment of seasonal carbon input into the East Kolkata Wetland ecosystem. Wetlands 37:497-512 https://doi. org/10.1007/s13157-017-0885-5

Pandi DP, Thena T, Nirmal B, Aswathy MR, Saravanan K, Mohan K (2017) Morphometric analyses of Neyyar River Basin, southern Kerala, India. Geology, Ecol Landscape 1:249-256 https://doi.org/10.1080/24749508.2017.1389494

Peralta G, Brun FG, Pérez-Lloréns JL, Bouma TJ (2006) Direct effects of current velocity on the growth, morphometry and architecture of seagrasses: a case study on Zostera noltii. Mar Ecol Prog Ser 327:135-42

Prabhakaran A, Raj NJ (2018) Drainage morphometric analysis for assessing form and processes of the watersheds of Pachamalai hills and its adjoinings, Central Tamil Nadu, India. Appl Water Sci 8:31 https://doi.org/10.1007/ s13201-018-0646-5

Rawat M, Arunachalam K, Arunachalam A (2015) Plant functional traits and carbon accumulation in forest. Clim Chang Environ Sustainability 3:1-12 https://doi.org/10.5958/2320-642X.2015.00001.0 
Reis V, Hermoso V, Hamilton SK, Ward D, Fluet-Chouinard E, Lehner B, Linke S (2017) A global assessment of inland wetland conservation status. Bioscience 67:523-533 https://doi.org/10.1093/biosci/bix045

Schneider B, Cunha ER, Marchese M, Thomaz SM (2018) Associations between macrophyte life forms and environmental and morphometric factors in a large sub-tropical floodplain. Front Plant Sci 9:195 https://doi.org/10.3389/ fpls.2018.00195

Shannon CE, Wiener W (1963) The mathematical theory of communication. University Illinois Press, Urbana

Sharpe PJ, Baldwin AH (2009) Patterns of wetland plant species richness across estuarine gradients of Chesapeake Bay. Wetlands 29:225-235

Simpson EH (1949) Measurement of diversity. Nature 163:688

Singh P, Gupta A, Singh M (2014) Hydrological inferences from watershed analysis for water resource management using remote sensing and GIS techniques. Egypt J Rem Sensing Space Sci 17:111-121 https://doi.org/10. 1016/j.ejrs.2014.09.003

Soni S (2017) Assessment of morphometric characteristics of Chakrar watershed in Madhya Pradesh India using geospatial technique. Appl Water Sci 7:20892102 https://doi.org/10.1007/s13201-016-0395-2

Sperling E (1999) Morfologia de lagos e represas. DESA/UFMG, Belo Horizonte, p

Stefanidis K, Papastergiadou E (2012) Relationships between lake morphometry, water quality, and aquatic macrophytes in greek lakes. Fresenius Environ Bull 21:3018-3026

Sullivan G, Callaway JC, Zedler JB (2007) Plant assemblage composition explains and predicts how biodiversity affects salt marsh functioning. Ecol Monogr 77 569-590 https://doi.org/10.1890/06-1947.1

Sultan SE (1995) Phenotypicplasticity and plant adaptation. Acta Botanica Neerlandica 44:363-383

Sutfin NA, Wohl EE, Dwire KA (2016) Banking carbon: a review of organic carbon storage and physical factors influencing retention in floodplains and riparian ecosystems. Earth Surf Process Landf 41:38-60 https://doi.org/10.1002/esp. 3857

Tang Z, Xu W, Zhou G, Bai Y, Li J, Tang X, Chen D, Liu Q, Ma W, Xiong G, He H (2018) Patterns of plant carbon, nitrogen, and phosphorus concentration in relation to productivity in China's terrestrial ecosystems. Proc Natl Acad Sci 115:4033-4038 https://doi.org/10.1073/pnas.1700295114

Ter Braak CJF, Smilauer P (2002) CANOCO reference manual and CanoDraw for Windows user's guide: software for canonical community ordination (version 4.5). www.canoco.com.

Tilman D, Downing JA (1994) Biodiversity and stability in grasslands. Nature 367: 363-365 https://doi.org/10.1038/367363a0

Tilman D, Reich PB, Knops JMH (2006) Biodiversity and ecosystem stability in a decade-long grassland experiment. Nature 441:629-632 https://doi.org/10. 1038/nature04742

Tockner K, Stanford JA (2002) Riverine flood plains: present state and future trends. Environ Conserv 29:308-330 https://doi.org/10.1017/ S037689290200022X

Van der Maarel E, Titlyanova A (1989) Above-ground and below-ground biomass relations in steppes under different grazing conditions. Oikos 56:364-370 https://doi.org/10.2307/3565622

Van Der Valk AG (2005) Water-level fluctuations in North American prairie wetlands. Hydrobiologia 539:171-188 https://doi.org/10.1007/s10750-0044866-3

Walling DE, Fang D, Nicholas AP, Sweet RJ, Rowan JS, Duck RW, Werritty A (2006) River floodplains as carbon sinks. IAHS Publ 306:460-470

Ward JV, Tockner K, Schiemer F (1999) Biodiversity of floodplain river ecosystems: ecotones and connectivity. River Res Appl 15:125-139

Warwick RM, Clarke KR (1995) New 'biodiversity' measures reveal a decrease in taxonomic distinctness with increasing stress. Mar Ecol Prog Ser 129:301-5

Watkins SC, Baldwin DS, Waudby HP, Ning SP (2017) Managing rain-filled wetlands for carbon sequestration: a synthesis. The Rangeland Jour 39:145152 https://doi.org/10.1071/RJ16077

Wetzel RG (2001) Limnology: lake and river ecosystems. 3rd edition, Academic Press, London

Woomer PL (1999) Impact of cultivation of carbon fluxes in woody savannas of South Africa. Water Air Soil Pollut 70:403-412 https://doi.org/10.1007/ BF01105011

Wright AJ, Ebeling A, De Kroon H, Roscher C, Weigelt A, Buchmann N, Buchmann T, Fischer C, Hacker N, Hildebrandt A, Leimer S (2015) Flooding disturbances increase resource availability and productivity but reduce stability in diverse plant communities. Nat Commun 6:6092. https://doi.org/10.1038/ ncomms7092.

Yunus AJM, Nakagoshi N, Salleh KO (2003) The effects of drainage basin geomorphometry on minimum low flow discharge: the study of small watershed in Kelang River Valley in Peninsular Malaysia. J Environ Sci 15:149262

Zedler JB, Kercher S (2005) Wetland resources: status, trends, ecosystem services, and restorability. Annu Rev Environ Resour 30:39-74 https://doi.org/10.1146/ annurev.energy.30.050504.144248

Zhao S, Peng C, Jiang H, Tian D, Lei X, Zhou X (2006) Land use change in Asia and the ecological consequences. Ecol Res 21:890-896

\section{Publisher's Note}

Springer Nature remains neutral with regard to jurisdictional claims in published maps and institutional affiliations.

\section{Submit your manuscript to a SpringerOpen ${ }^{\circ}$ journal and benefit from:}

- Convenient online submission

- Rigorous peer review

- Open access: articles freely available online

- High visibility within the field

- Retaining the copyright to your article

Submit your next manuscript at $\boldsymbol{\nabla}$ springeropen.com 